\title{
Synopsis of the
}

Parasites of

Vertebrates

of Canada

Edited by Murray J. Kennedy

\section{Parasites of}

\section{Marine Mammals}

Leo Margolis

Hisao P. Arai 


\section{National Library Bibliotheque nationale
of Canada}

Other titles in this series -

Synopsis of the Parasites of Vertebrates of Canada

- Helminths and Protozoa of Terrestrial Mammals

Murray J. Kennedy, 1986

Synopsis of the Parasites of Vertebrates of Canada

- Ectoparasites of Terrestrial Mammals

Murray J. Kennedy and Robert A. Newman, 1986

Synopsis of the Digenea of Mammals of North America

Murray J. Kennedy, 1988

Synopsis of the Parasites of Domesticated Mammals of Canada

Murray J. Kennedy, 1988

Copies of these publications are available from the

Queen's Printer, 11510 Kingsway Avenue, Edmonton T5G 2Y5

Each order for a copy of this publication must be accompanied by a cheque for $\$ 5.00$ made out to The Provincial Treasurer 


\section{Synopsis of the}

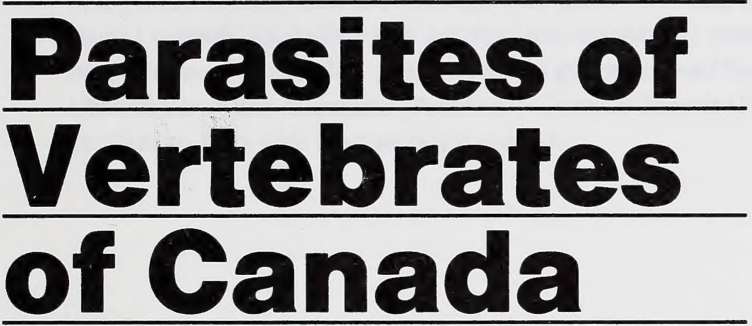

Edited by Murray J. Kennedy ${ }^{1}$

\section{Parasites of}

Marine Mammals

Leo Margolis 2

Hisao P. Arai ${ }^{3}$

\section{${ }^{1}$ Alberta Agriculture}

Veterinary Laboratory

6909 - 116 Street

Edmonton, Alberta

Canada T6H 4P2

2 Department of Fisheries and Oceans

Biological Sciences Branch

Pacific Biological Station

Nanaimo, British Columbia

Canada V9R 5K6

3 Department of Biological Sciences

University of Calgary

Calgary, Alberta

Canada T2N 1 N4 


\begin{abstract}
This synopsis contains Parasite-Host and Host-Parasite lists for 74 species of parasites from 26 species (1 with 2 subspecies) of marine mammals from Canadian waters. The 74 species are distributed among higher taxa as follows: Protozoa - 2; Trematoda - 9; Cestoidea - 9; Nematoda - 24; Acanthocephala - 10; Copepoda - 1; Amphipoda - 13; Anoplura - 3; and Acarina - 3. Eighteen previously unpublished host-parasite-locality records are added to the faunal records, including five species (one unnamed) previously unreported from Canadian waters: Hadwenius nipponicus (Trematoda), Placentonema gigantissima (Nematoda), Corynosoma ?similis (Acanthocephala), and Orthohalarachne attenuata (Acarina). Cyamus boopis (Amphipoda) from Balaenoptera physalus in Atlantic waters appears to be a new host-parasite record.
\end{abstract}




\section{Forward}

Records of parasites found in Canadian animals go back almost 200 years, when de La Martinière (1787) described a monogenean from a fish taken off the west coast of Vancouver Island during the La Perouse Expedition, while more comprehensive faunal lists date back to the 1850 s e.g. Stimpson (1854). Margolis and Arthur (1979) in their introduction to the Synopsis of the Parasites of Fishes of Canada outlined the steady increase in volume in investigations into fish parasites and a similar escalation is apparent when one considers other vertebrate host taxa: Amphibians, Reptiles, Birds and Mammals.

The possibility of producing a synoptic coverage of parasites of animals of Canada was first raised at a meeting of the Executive Committee of the Parasitology Section of the Canadian Society of Zoologists in 1978 by Leo Margolis. A committee was established to examine the feasibility of the proposal. In 1982, Smith and Addison published a Bibliography of Parasites and Diseases of Ontario Wildlife, which provided an extensive coverage of known pathogens (including bacteria, fungi, rickettsiae, helminths, insects, arachnids, "anatomical disorders", "environmental contaminants", genetic, nutritional and reproductive disorders, protists and viruses). With the publication of the above synopsis and bibliographies (Margolis and Arthur, 1979 and Smith and Addison, 1982) the worth of providing synopses/bibliographies of the parasites of all vertebrate groups in Canada became increasingly obvious. Thus, in 1983 the question of the synopsis was resuscitated and the Executive Committee of the Parasitology Section under the Chairmanship of Charles Tanner approved coverage of the vertebrate hosts.

The Executive Committee had hoped to publish the synopsis in 1986 to commemorate the 25th anniversary of the Canadian Society of Zoologists. Unfortunately lack of funding became a major barrier to progress and the series, which was almost 50 per cent completed, remained in manuscript form. With the appearance of Dr. Kennedy's two synopses in 1986 the possibility of publishing the synopsis under the aegis of Alberta Agriculture became a possibility. In conversation with Dr. Kennedy he assured me of his enthusiastic support for this approach, and his willingness to act as editor for the series. In $1988 \mathrm{Mr}$. Ben McEwan, Deputy Minister of Alberta Agriculture approved the initiative, and the editorship transferred from me to Murray Kennedy. The publication of the series will continue with the present volume being the first in the series. Each part will be published as it is completed, rather than adhering to a systematic ordering, and each will have an introduction to include pertinent background of the taxa under consideration.

The authority for the taxonomic arrangement of the major hosts and parasite groups will be declared for each volume. Although we recommend a uniform classificatory scheme be used for the parasites throughout the series, the difficulties of adhering to any one classification are well known and need not be enumerated here. Therefore, some flexibility has been allowed.

It is my hope that updated synopses and bibliographies will be produced at appropriate intervals in the future and that the present series represents a foundation.

Mary Beverley-Burton

University of Guelph

College of Biological Sciences

Guelph, Ontario

Kennedy, M.J. 1986. Synopsis of the Parasites of Vertebrates of Canada-Helminths and Protozoa of Terrestrial Mammals. Alberta Agriculture Publication. 90 p.

Kennedy, M.J., and R.A. Newman. 1986. Synopsis of the Parasites of Vertebrates of Canada-Ectoparasites of Terrestrial Mammals. Alberta Agriculture Publication. 109 p.

de La Martinière. 1787. Mémoire sur quelques insectes. Obs. Sur. Phys. (etc)., Vol. 31, Pt2, Sept., p. 207-209, pl. 2. fig. 1-7; Oct., p. 264-266, pl. 2. fig. 8-12; Nov., p 365-366, pl. 2, fig. 13-15.

Margolis, L., and J.R. Arthur. 1979. Synopsis of the Parasites of Fishes of Canada. Bulletin of the Fisheries Research Board of Canada 199: $269 \mathrm{p}$.

Smith, L.M., and E.M. Addison. 1982. A Bibliography of Parasites and Diseases of Ontario Wildlife. Ontario Ministry of Natural Resources. Wildlife Research Report No. 99: 267 p.

Stimpson, W. 1854. Synopsis of the Marine Invertebrates of Grand Manan: or the region about the mouth of the Bay of Funday, New Brunswick. Smithsonian Contribution to Knowledge 6: 1-66. 
Digitized by the Internet Archive in 2015

https://archive.org/details/synopsisofparasi00marg 


\section{Introduction}

Although the earliest record of a parasite from marine mammals taken in Canadian waters may date back to 1853, the parasite fauna of these mammals in Canadian waters is far from adequately known. Undoubtedly, more intensive studies than have been conducted to date would bring to light the existence in this fauna of additional species of parasites and would provide further host and distributional records. Indeed, many parasite species not known from Canadian waters have been reported from other geographic areas in marine mammals that are found also in Canadian waters; some of these sea mammals are highly migratory and occur only seasonally in Canadian waters. The present compilation must, therefore, be regarded as indicative only of the present state of knowledge and not as a definitive synopsis of the fauna. Users of the synopsis are cautioned to bear this in mind, particularly when comparisons with other geographic areas are being attempted.

Only species considered to be obligatory and permanent parasites are included herein. Organisms that are more properly classified as commensals (e.g., the nematode Odontobius ceti Roussel de Vaużeme, 1834 and the copepod Balaenophilus unisetus Aurivillius, 1879, which live on the baleen plates of whales) or that have a phoretic relationship with marine mammals (e.g., various barnacles), and the lampreys, which are regarded either as temporary parasites or predators, are excluded.

Two known fish parasites that have been reported from marine mammals are not included in the present synopsis. They are the cestode Abothrium gadi van Beneden, 1871, reported by Margolis (1956) from Eumetopias jubatus from the Pacific coast and the nematode Hysterothylacium aduncum (Rudolphi, 1802) [recorded as Contracaecum gadi (O. F Müller, 1777)], reported by Ronald et al. (1970) from Pagophilus (= Phoca) groenlandicus from the Atlantic coast. The occurrence of these helminths in marine mammals likely resulted from recent ingestion of infected fish and they should not be considered as true parasites of these mammals.

The synopsis indicates that up to October 1988, at least 69 species of parasites have been reported from 26 species ( 1 with 2 subspecies) of marine Carnivora and Cetacea. Five additional species (one unnamed) from previously unpublished data in the files of one of us (L.M.) are also listed in the synopsis. Parasites not identified to the species level are not included in the total number, except in cases where named species have not been recorded in Canadian waters for the genus in question or clearly a separate species is involved. The $\mathbf{7 4}$ species are divided among major taxa as follows: Protozoa -2; Trematoda -9; Cestoidea -9; Nematoda -24; Acanthocephala -10; Copepoda -1; Amphipoda -13; Anoplura -3; and Acarina -3.
Eighteen previously unpublished host-parasite-locality records from the files of L.M. are included in the present synopsis and are designated in the Parasite-Host list as "previously unpublished." They are:

1. Campula oblonga Cobbold, 1858 (Trematoda) from Phocoena phocoena and Phocoenoides dalli; Pacific coast.

2. Hadwenius nipponicus Yamaguti, 1951 (Trematoda) from Phocoena phocoena; Pacific coast.

3. Plicobothrium globicephalae Rausch and Margolis, 1969 (Cestoidea) from Lagenorhynchus albirostris; Atlantic coast.

4. Phyllobothrium delphini (Bosc, 1802) (Cestoidea) from Balaenoptera physalus; Atlantic coast.

5. Anisakis physeteris Baylis, 1923 (Nematoda) from Physeter catodon; Atlantic coast.

6. Anisakis simplex (Rudolphi, 1809) from Balaenoptera acutorostrata, Balaenoptera physalus, Phocoena phocaena, and Physeter catodon; Atlantic coast.

7. Anisakis simplex (Rudolphi, 1809) from Phocoena phocoena; Pacific coast.

8. Crassicauda sp. (Nematoda) from Phocoena phocoena; Pacific coast.

9. Placentonema gigantissima Gubanov, 1951 (Nematoda) from Physeter catodon; Pacific coast.

10. Bolbosoma sp. (Acanthocephala) from Balaenoptera physalus; Pacific coast.

11. Corynosoma sp. (? similis Neiland, 1962) (Acanthocephala) from Phocoena phocoena; Pacific coast.

12. Cyamus boopis Luitken, 1870 (Amphipoda) from Balaenoptera physalus; Atlantic coast. This also appears to be a new host-parasite record.

13. Orthohalarachne attenuata (Banks, 1910) (Acarina) from Callorhinus ursinus; Pacific coast.

14. Orthohalarachne diminuata (Doetschman, 1944) from Callorhinus ursinus; Pacific coast.

Of the above 14 parasite species, five are reported from Canada for the first time: Hadwenius nipponicus, Crassicauda sp. (unnamed), Placentonema gigantissima, Corynosoma? similis, and Orthohalarachne attenuata.

The classification and nomenclature of parasite taxa used herein generally follows currently accepted taxonomic systems. However, as has been emphasized by Gibson (1987), there has been no single system of trematode classification that has met with wide acceptance. We have chosen to use the classification and nomenclature recently proposed by Brooks et al. (1985), with addition of the superfamily Notocotyloidea. For Protozoa we used the system proposed by Levine et al. (1980); for Cestoidea, Nematoda, and Acanthocephala, we adopted the systems of Schmidt (1986), Anderson et al. (1974-1983), and Amin (1985), respectively. The 
arthropod parasites covered in this synopsis have been grouped in the classical way under the classes Crustacea (Copepoda and Amphipoda), Insecta (Anoplura), and Arachnoidea (Acarina).

Host nomenclature and classification conform to the usage of Banks et al. (1987). In addition, two subspecies of the harbor seal are recognized. In accordance with the arguments presented by Shaughnessy and Fay (1977), the subspecific name of the Pacific coast harbor seal is spelled richardsi. All Atlantic and eastern Arctic records from the harbor seal are assigned to the subspecies concolor, although most authors did not include a subspecific name for this seal.

The format of the entries in the synopsis follows that used by Margolis and Arthur (1979) in their Synopsis of the Parasites of Fishes of Canada.

The PARASITE-HOST list is organized by higher taxa of parasites in the following order: Protozoa (Apicomplexa), Platyhelminthes (Trematoda, Cestoidea), Nemathelminthes (Nematoda), Acanthocephala, and Arthropoda (Crustacea: Copepoda, Amphipoda; Insecta:

Anoplura; Arachnoidea: Acarina). Species, genera, and families are listed in alphabetical order within their respective next higher taxon, which in the case of a family is a superfamily, a suborder, or an order, depending on the group in question and the usefulness of including the superfamily or suborder category.

For each parasite species listed, the following information is provided:

1) The current scientific name, including author(s) and date(s), followed by any recognized synonyms that have been used in establishing the Canadian record(s). No attempt has been made to evaluate systematically the validity of published records, but attention is drawn to obvious errors.

2) The site of occurrence of the parasite in its host(s) (aberrant sites usually are not included). When the site was not given, the likely site as determined from other records, is enclosed in square brackets.
3) The hosts. Only currently accepted scientific names as recommended by Banks et al. (1987) are given in the Parasite-Host List. Numbers in parentheses after each host name correspond with the numbers assigned to the references establishing the particular parasite-host records.

4) Distribution (Dist.) within Canadian waters. The species are grouped into four geographic regions or localities: Atlantic (Atl), Pacific (Pac), Eastern Arctic (E Arc), and Western Arctic (W Arc). Eastern and Western Arctic are divided by $100^{\circ} \mathrm{W}$ longitude. The Eastern Arctic is generally defined as north of $60^{\circ} \mathrm{N}$ latitude, except that it includes Hudson Bay and Ungava Bay.

5) Authors responsible for the records are listed in chronological order of the published records. To enable the reader to grasp at a glance the author(s) responsible for particular parasitehost-locality records, we numbered the references listed under "Records" and placed the corresponding number(s) after the host name, and each reference is followed by the locality or localities from which the parasite was (were) reported. When only one host is listed for a particular parasite the references are not numbered, and when all records are from the same locality the latter is not listed after the authors' names.

6) Under Remarks, explanatory comments, as required, are offered on systematics, nomenclature, misidentifications, and synonymies of parasites; and on the hosts, sites within hosts, and validity of previous records.

In the HOST-PARASITE LIST, within each order or suborder, the families, genera, species, and subspecies are listed alphabetically. Host synonyms included are only those that were used in establishing the Canadian parasite records. After the name of each parasite species, its geographic distribution in the host in question is given in parentheses. 


\section{PARASITE-HOST LIST}



SUBKINGDOM PROTOZOA

PHYLUM APICOMPLEXA

CLASS SPOROZOEA SUBCLASS COCCIDIA

ORDER EUCOCCIDIIDA SUBORDER EIMERIINA

\section{FAMILY EIMERIIDAE}

Eimeria phocae Hsu, Melby and Altman, 1974

Site: unspecified

Host: Phoca vitulina concolor

Dist.: Atl

Record: McClelland 1980c

\section{FAMILY SARCOCYSTIDAE}

Sarcocystis $\mathrm{sp}$.

Sites: skeletal muscles, myocardium

Host: Globicephala melaena

Dist.: Atl

Record: Cowan 1966

\section{SUBKINGDOM EUMETAZOA} PHYLUM

PLATYHELMINTHES

CLASS TREMATODA
SUBCLASS DIGENEA

\section{ORDER PARAMPHISTOMIFORMES}

\section{SUPERFAMILY NOTOCOTYLOIDEA \\ FAMILY NOTOCOTYLIDAE}

Ogmogaster antarcticus Johnston, 1931

Syn.: Ogmogaster plicatus of Margolis and Pike (1955), in part

Site: large intestine

Host: Balaenoptera borealis

Dist.: Pac

Record: Rausch and Fay 1966

Ogmogaster plicatus (Creplin, 1829)

Jägerskiöld, 1891

Site: small intestine

Hosts: Balaenoptera borealis $(1,2)$

Balaenoptera physalus $(1,2)$

Balaenoptera sp. (3)

Dist.: Pac

Records: 1. Margolis and Pike 1955; 2. Rausch and Fay 1966; 3. Gibson and Harris 1979
ORDER ECHINOSTOMATIFORMES

\section{SUPERFAMILY FASCIOLOIDEA \\ FAMILY CAMPULIDAE}

Campula oblonga Cobbold, 1858

Site: bile ducts

Hosts: Phocoena phocoena $(1,2)$

Phocoenoides dalli (2)

Dist.: Atl, Pac

Records: 1. Smith and Threlfall 1973 (Atl); 2.

Previously unpublished (Pac)

Remarks: Smith and Threlfall (1973) did not specify the site in which their specimens from $P$. phocoena were found, but presumably it was the bile ducts.

Hadwenius nipponicus Yamaguti, 1951

Site: stomach

Host: Phocoena phocoena

Dist.: Pac

Record: Previously unpublished

Hadwenius seymouri Price, 1932

Site: intestine

Host: Delphinapterus leucas

Dist.: W Arc

Record: Wazura et al. 1986

Lecithodesmus goliath (van Beneden, 1858) Odhner, 1905

Site: bile ducts

Host: Balaenoptera physalus

Dist.: Pac

Record: Margolis and Pike 1955

Lecithodesmus spinosus Margolis and Pike, 1955

Site: bile ducts

Host: Balaenoptera borealis

Dist.: Pac

Record: Margolis and Pike 1955

Leucasiella arctica Delyamure and Kleinenberg, 1958

Site: rectum

Host: Delphinapterus leucas

Dist.: W Arc

Record: Wazura et al. 1986

Orthosplanchnus arcticus Odhner, 1905

Site: liver, bile ducts

Hosts: Globicephala melaena $(2,3)$

Phoca hispida (1)

Dist.: Atl, W Arc

Records: 1. Cooper 1921 (W Arc); 2. Cowan 1966 (Atl); 3. 1967 (Atl)

Remarks: Cowan (1966) initially reported this species simply as "trematode worms." 


\section{CLASS CESTOIDEA SUBCLASS EUCESTODA}

ORDER PSEUDOPHYLLIDEA

FAMILY DIPHYLLOBOTHRIIDAE

Diphyllobothrium cordatum (Leuckart, 1863)

Gedoelst, 1911

Site: intestine

Host: Erignathus barbatus

Dist.: E Arc, W Arc

Records: Cooper 1921 (W Arc); Markowski 1952 (E Arc)

Diphyllobothrium lanceolatum (Krabbe, 1865)

Cooper, 1921

Syn.: Cordicephalus phocarus Wardle, McLeod and Stewart, 1947, in part ("type 2" of

Wardle et al. 1947)

Site: intestine

Hosts: Erignathus barbatus $(1,2,3)$

Phoca groenlandica $(2,3)$

Dist.: Atl, E Arc, W Arc

Records: 1. Cooper 1921 (W Arc); 2. Wardle, McLeod and Stewart 1947 (Atl); 3.

Markowski 1952 (E Arc)

Diphyllobothrium pacificum (Nybelin, 1931)

Margolis, 1956

Site: intestine

Host: Eumetopias jubatus

Dist.: Pac

Record: Margolis 1956

Diphyllobothrium spp.

Site: intestine

Hosts: Erignathus barbatus $(1,2)$

Globicephala melaena (4)

Phoca groenlandica $(2,3)$

Dist.: Atl, E Arc, W Arc

Records: 1. Cooper 1921 (W Arc); 2. Lyster

1940 (E Arc); 3. Markowski 1952 (E Arc);

4. Cowan 1967 (Atl)

Remarks: Lyster (1940) suggested that his specimens might belong to Diphyllobothrium lanceolatum.

Diplogonoporus tetrapterus (von Siebold, 1848)

Ariola, 1896

Site: intestine

Host: Eumetopias jubatus

Dist.: Pac

Record: Margolis 1956
Diplogonoporus sp.

Site: intestine

Hosts: Erignathus barbatus

Phoca groenlandica

Dist.: Atl

Record: Wardle et al. 1947

Remarks: Wardle et al. (1947) described a diplogonadic cestode (their "type 1"), which they considered reminiscent of Diplogonoporus fasciatus (Krabbe, 1865). They included it in their new genus Cordicephalus, as C. phocarus (Fabricius, 1780). However, Cordicephalus has not been accepted as a valid genus, nor is fasciatus a synonym of phocarus (see Stunkard 1948; Markowski 1952). We here assign Wardle et al.'s (1947) "type 1" diphyllobothriid to Diplogonoporus.

Plicobothrium globicephalae Rausch and Margolis, 1969

Site: small intestine

Hosts: Globicephala melaena (1) Lagenorhynchus albirostris (2)

Dist.: Atl

Records: 1. Rausch and Margolis 1969; 2. Previously unpublished

Pyramicocephalus phocarum (Fabricius, 1780) Monticelli, 1890

Syn.: Bothriocephalus anthocephalus of Baird (1853)

Site: intestine

Host: Erignathus barbatus

Dist.: Atl, E Arc, W Arc

Records: Baird 1853 (E Arc); Cooper 1921 (W Arc); Markowski 1952 (E Arc)

Remarks: Baird (1853) reported B. anthocephalus, which Markowski (1952) considered as a synonym of $P$. phocarum, from Baffin Bay. Although the precise locality was not indicated, we are including this record here because of the possibility that it pertains to Canadian waters.

\section{ORDER TETRAPHYLLIDEA}

\section{FAMILY PHYLLOBOTHRIIDAE}

Phyllobothrium delphini (Bosc, 1802) van Beneden, 1870

Site: blubber

Hosts: Balaenoptera physalus $(1,3)$

Globicephala melaena (2)

Physeter catodon (1)

Dist.: Atl, Pac

Records: 1. Margolis and Pike 1955 (Pac); 2. Sergeant 1962 (Atl); 3. Previously unpublished (Atl) 
Phyllobothrium sp.

Sites: abdominal subserosa, blubber

Host: Globicephala melaena

Dist.: Atl

Records: Cowan 1966, 1967

Remarks: The cestode plerocercoids reported by Cowan (1966) were subsequently assigned by him (Cowan 1967) to Phyllobothrium sp.

\section{ORDER CYCLOPHYLLIDEA}

\section{FAMILY TETRABOTHRIIDAE}

Anophryocephalus anophrys Baylis, 1922

Site: [intestine]

Host: Phoca groenlandica

Dist.: Atl

Record: Smith and Threlfall 1973

Anophryocephalus sp.

Syn.: Anophryocephala sp. of McClelland (1980c)

Site: intestine

Host: Phoca vitulina concolor

Dist.: Atl

Record: McClelland 1980c

Trigonocotyle lintoni Guiart, 1935

Site: intestine

Host: Globicephala melaena

Dist.: Atl

Record: Cowan 1967

Remarks: In his Handbook of Tapeworm Identification, Schmidt (1986) listed this species as Trigonocotyle monticellii (Linton, 1923) Baer, 1932, with $T$. lintoni Guiart, 1935 as one of its synonyms. However, in accordance with Article 52(b) of the International Code of Zoological Nomenclature (3rd edition, 1985), "monticellii," as a junior primary homonym, is a permanently invalid name for this tapeworm. Contrary to the views expressed by Baer (1954), who reviewed the nomenclatural history of this species and proposed for it yet another new specific name (globicephalae), the next available name for the cestode in question is "lintoni." Guiart (1935) explicitly applied this name as a replacement for the homonym "monticellii," although unfortunately he proceeded to describe under the name Trigonocotyle lintoni a different species, which Baer (1954), upon re-examination, considered to be Tetrabothrius forsteri (Krefft, 1871).

\section{UNIDENTIFIED CESTOIDEA}

Cestoidea gen. spp.

Sites: intestine, stomach

Hosts: Balaenoptera borealis and/or Megaptera novaeangliae (1)
Dist: E Arc, Pac

Erignathus barbatus (2)

Records: 1. Cornwall 1928 (Pac); 2. Dunbar 1949 (E Arc)

\section{PHYLUM \\ NEMATHELMINTHES \\ CLASS NEMATODA SUBCLASS ADENOPHOREA}

\author{
ORDER ENOPLIDA
}

\section{SUPERFAMILY TRICHINELLOIDEA FAMILY TRICHINELLIDAE}

Trichinella spiralis (Owen, 1835) Raillient, 1895

Site: musculature

Hosts: Erignathus barbatus (2)

Odobenus rosmarus $(1,2)$

Dist: E Arc

Records: 1. Kuitunen-Ekbaum 1954; 2.

Mansfield (1963)

SUBCLASS SECERNENTEA

ORDER ASCARIDIDA

\section{SUPERFAMILY ASCARIDOIDEA FAMILY ANISAKIDAE}

Anisakis physeteris Baylis, 1923

Site: stomach

Host: Physeter catodon

Dist.: Atl, Pac

Records: Margolis and Pike 1955 (Pac);

Previously unpublished (Atl)

Anisakis simplex (Rudolphi, 1809) Baylis, 1920

Site: stomach

Hosts: Balaenoptera acutorostrata (12)

Balaenoptera borealis $(1,2,3,10)$

Balaenoptera physalus (12)

Berardius Bairdii (7)

Delphinapterus leucas $(4,5,6,13)$

Globicephala melaena (8)

Orcinus orca $(9,10)$

Phocoena phocoena (11)

Phocoenoides dalli (10)

Physeter catodon $(7,12)$

Dist.: Atl, E Arc, Pac, W Arc

Records: 1. Mueller 1927a (Pac); 2. 1927b

(Pac); 3. Cornwall 1928 (Pac); 4. Lyster 1940

(Atl); 5. Vladykov 1944 (Atl); 5. Doan and

Douglas 1953 (E Arc); 7. Margolis and Pike 1955 (Pac); 8. Sergeant 1962 (Atl); 9. Newman and McGeer 1966 (Pac); 10. Margolis and Dailey 1972 (Pac); 11. Previously unpublished $(\mathrm{Pac}) ; 12$. Previously unpublished (Atl); 13. Wazura et al. 1986 (W Arc) 
Remarks: Davey (1971) attributed records of $A$. simplex from $O$. orca, $P$. dalli, and Megaptera novaeangliae to Margolis and Pike (1955). However, the first records of $A$. simplex from $O$. orca and $P$. dalli from Canadian waters were reported by Margolis and Dailey (1972). A confirmed record of A. simplex from Megaptera novaeangliae in Canadian waters is still not documented, although Margolis and Pike (1955) reported Anisakis sp. from this host.

Anisakis sp.

Site: gastrointestinal tract

Hosts: Balaenoptera physalus (2)

Delphinapterus leucas (1)

Globicephala melaena $(5,6)$

Halichoerus grypus $(4,7)$

Lagenorhynchus albirostris (3)

Megaptera novaeangliae (2)

Phoca groenlandica (8)

Phoca vitulina concolor $(4,8)$

Pseudorca crassidens (9)

Dist.: Atl, E Arc, Pac

Records: 1. Lyster 1940 (E Arc); 2. Margolis and Pike 1955 (Pac); 3. Sergeant and Fisher 1957 (Atl); 4. Scott and Fisher 1958b (Atl); 5. Cowan 1966 (Atl); 6. Cowan 1967 (Atl); 7. Mansfield and Beck 1977 (Atl); 8.

McClelland 1980c, experimental and natural (Atl); 9. Previously unpublished (Pac)

Remarks: The nematodes reported by Cowan (1966) from the "true (peptic) stomach" of $G$. melaena are included here because it appears that he subsequently identified them as Anisakis sp. (Cowan 1967). The unpublished record from $P$. crassidens pertains to larval worms.

Contracaecum osculatum (Rudolphi, 1802) Baylis, 1920

Syn.: Ascaris osculata Rudolphi, 1802 of Baird (1853)

Site: stomach

Hosts: Erignathus barbatus $(1,5)$

Eumetopias jubatus (4)

Halichoerus grypus (9)

Phoca groenlandica $(5,6,7)$

Phoca hispida $(2,5)$

Phoca vitulina concolor $(2,5)$

Phoca vitulina richardsi $(3,4)$

Dist.: Atl, E Arc, Pac, W Arc

Records: 1. Baird 1853 (E Arc); 2. Lyster 1940

(Atl, E Arc); 3. Fisher 1952 (Pac); 4. Margolis

1956 (Pac); 5. Myers 1957a (E Arc, W Arc);

6. 1957b (Atl); 7. Smith and Threlfall 1973

(Atl); 8. McClelland 1980c (Atl); 9.

McClelland et al. 1987 (Atl)
Remarks: Lyster (1940) reported C. osculatum from $P$. hispida and $P$. vitulina from several localities in the eastern Arctic and the Atlantic regions, but the localities were not segregated by host. We arbitrarily assigned all records from $P$. hispida to the eastern Arctic and the records from $P$. vitulina to both the eastern Arctic and Atlantic regions. Ascaris osculata of Baird (1853) was reported from an unspecified locality in Baffin Bay. We are including the record here because of the possibility that it pertains to Canadian waters.

Contracaecum spp.

Syn.: Phocascaris sp. of Myers (1957a, b) and of McClelland (1980c)

Sites: stomach, less commonly intestine

Hosts: Delphinapterus leucas (8)

Halichoerus grypus $(3,6)$

Phoca groenlandica $(2,3,4,7)$

Phoca hispida (1)

Phoca vitulina concolor (3)

Phocoena phocoena (5)

Dist.: Atl, E Arc, W Arc

Records: 1. Myers 1957a (E Arc); 2. 1957b (Atl); 3. Scott and Fisher 1958b (Atl); 4. Wilson and Stockdale 1970 (locality not specified); 5. Smith and Threlfall 1973 (Atl); 6. Mansfield and Beck 1977 (Atl); 7.

McClelland 1980c (Atl); 8. Wazura et al. 1986 (W Arc)

Remarks: Phocascaris was declared a synonym of Contracaecum by Soleim (1984). The records of Myers (1957a, b) and McClelland (1980c) were reported as Phocascaris sp. Wilson and Stockdale (1970) did not specify the locality of capture or captivity of the harp seal they examined. Stockdale (pers. comm. 1985) advised that the seal was one of a group obtained from eastern Canada and maintained at the University of Guelph.

Phocascaris netsiki Lyster, 1940

Site: stomach

Hosts: Phoca hispida

Phoca vitulina concolor

"seal"

Dist.: E Arc

Record: Lyster 1940

Remarks: Soleim (1984) placed the genus Phocascaris in synonymy with Contracaecum. Although he mentioned P. cystophorae and $P$. phocae (but not $P$. netsikl) as species in Phocascaris, he did not formally establish new combinations for these species in the genus Contracaecum. Pending clarification of the status of $P$. netsiki, we are retaining it in Phocascaris. In the summary host-parasite list 
in Lyster's (1940) paper, $P$. vitulina is included as a host of $P$. netsiki, although this species of seal is not mentioned as a host in the text.

Pseudoterranova decipiens (Krabbe, 1878) Gibson and Colin, 1982

Syn.: Porrocaecum decipiens (Krabbe, 1878)

Baylis, 1920

Terranova decipiens (Krabbe, 1878)

Mozgovoy, 1951

Phocanema decipiens (Krabbe, 1878)

Myers, 1959

Site: gastrointestinal tract

Hosts: Delphinapterus leucas (9)

Erignathus barbatus $(1,7)$

Eumetopias jubatus (6)

Halichoerus grypus $(2,10,11,12,13,14$, $16,17,18,19,20,22,23)$

Phoca groenlandica $(1,8,10,11$, $15,18,21)$

Phoca hispida (7)

Phoca vitulina concolor $(1,2,4,5,7,10$, $11,12,13,14,16,17,18,19,20,21,22)$

Phoca vitulina richardsi $(3,6)$

Phocoena phocoena (9)

"seals" (1)

Dist.: Atl, E Arc, Pac

Records: 1. Lyster 1940 (Atl, E Arc); 2. Scott 1950 (Atl); 3. Fisher 1952 (Pac); 4. Scott 1953, experimental and natural (Atl); 5. 1955, experimental (Atl); 6. Margolis 1956 (Pac); 7. Myers 1957a (E Arc); 8. 1957b (Atl); 9. Scott and Fisher 1958a (Atl); 10. 1958b (Atl); 11. Myers 1960 (Atl); 12. Scott and Black 1960 (Atl); 13. Mansfield 1963 (Atl); 14. McClelland and Ronald 1970 (Atl); 15. Ronald et al. 1970 (Atl); 16. McClelland and Ronald 1974 (Atl); 17. McClelland 1976, experimental (Atl); 18. Mansfield and Beck 1977 (Atl); 19. McClelland 1980a, experimental (Atl); 20. 1980b, experimental (Atl); 21. 1980c, experimental and natural (Atl); 22. 1982 (Atl); 23. McClelland et al. 1987 (Atl)

Remarks: All records cited above were reported under one or other of the synonyms listed above. We accept Gibson and Colin's (1982) and Gibson's (1983) arguments that the valid generic name for this nematode is Pseudoterranova.

Anisakinae gen. sp.

Site: gastrointestinal tract

Hosts: Halichoerus grypus

Phoca groenlandica

Phoca vitulina concolor
Dist.: Atl

Record: Montreuil and Ronald 1957

ORDER SPIRURIDA

\section{SUPERFAMILY HABRONEMATOIDEA FAMILY TETRAMERIDAE}

Crassicauda boopis Baylis, 1920

Syn.: Crassicauda pacifica Margolis and Pike, 1955

Site: kidneys

Host: Balaenoptera physalus

Dist.: Pac

Record: Margolis and Pike 1955

Remarks: Crassicauda boopis and C. pacifica were originally described from posterior and anterior regions, respectively, of these worms, which are difficult to dissect from host tissues in their entirety. Lambertsen (1985) obtained a single whole specimen, which enabled him to demonstrate that $C$. pacifica is a synonym of C. boopis.

Crassicauda sp.

Site: cavities within the blubber

Host: Phocoena phocoena

Dist.: Pac

Record: Previously unpublished

Remarks: This species is distinct from C. boopis, found in certain larger baleen whales. It is unquestionably identical with the unnamed Crassicauda sp. reported by Dailey and Stroud (1978) from the blubber, mammary glands, and urogenital system of $P$. phocoena stranded on the shores of Oregon, U.S.A.

Placentonema gigantissima Gubanov, 1951

Site: placenta

Host: Physeter catodon

Dist.: Pac

Record: Previously unpublished

\section{SUPERFAMILY FILARIOIDEA FAMILY ONCHOCERCIDAE}

Dipetalonema spirocauda (Leidy, 1858) Anderson, 1959

Site: aorta

Host: Phoca vitulina concolor

Dist.: Atl

Record: McClelland 1980c

ORDER STRONGYLIDA

SUPERFAMILY ANCYLOSTOMATOIDEA

FAMILY ANCYLOSTOMATIDAE 
Uncinaria lucasi Stiles, 1901 (adults and larvae)

Sites: intestine (adults), blubber (larvae)

Host: Callorhinus ursinus

Dist.: Pac

Records: Bigg and Lyons 1981; Lyons and Bigg 1983

Remarks: These records represent infections passed to pups born in captivity (in Nanaimo, B.C.) through transmammary transmission from naturally infected mothers captured on the Pribilof Islands, Alaska.

\section{SUPERFAMILY METASTRONGYLOIDEA FAMILY FILAROIDIDAE}

Filaroides (Parafilaroides) hispidus Kennedy, 1986

Site: lungs

Host: Phoca hispida

Dist.: W Arc

Record: Kennedy 1986

Filaroides (Parafilaroides) sp.

Syn.: Parafilaroides sp. of Margolis, 1956

Site: lungs

Host: Eumetopias jubatus

Dist.: Pac

Record: Margolis 1956

\section{FAMILY PSEUDALIIDAE}

Halocercus invaginatus (Quekett, 1841) Dougherty, 1943

Syn.: Halocercus inflexicaudatus of Smith and Threlfall (1973)

Site: lungs

Host: Phocoena phocoena

Dist.: Atl, Pac

Records: Smith and Threlfall 1973 (Atl); Arnold and Gaskin 1975 (Atl, Pac)

Halocercus monoceris Webster, Neufeld and MacNeil, 1973

Site: lungs

Host: Monodon monoceros

Dist.: E Arc

Records: Webster, Neufeld and MacNeil 1973; MacNeil, Neufeld and Webster 1975

Remarks: This species was recovered from narwhals captured in the eastern Arctic and transported to the Vancouver aquarium, where they died.

Halocercus taurica Delyamure, 1942

Site: lungs

Host: Phocoena phocoena

Dist.: Atl, Pac

Record: Arnold and Gaskin 1975
Halocercus sp.

Site: lungs

Host: Phocoena phocoena

Dist.: Atl

Record: Smith and Threlfall 1973

Pharurus alatus (Leuckart, 1848) Stiles and Hassall, 1905

Site: lungs

Host: Monodon monoceros

Dist.: E Arc

Record: Arnold and Gaskin 1975

Pharurus pallasii (van Beneden, 1870) Arnold and Gaskin, 1975

Syn.: Stenurus arcticus (Cobb, 1888)

Crassicauda sp. of Brodie (1971)

Sites: lungs, cranial sinuses, cerebral spinal

fluid, auditory canals

Host: Delphinapterus leucas

Dist.: Atl, E Arc, W Arc

Records: Doan and Douglas 1953 (E Arc); Brodie 1971 (E Arc); Arnold and Gaskin 1975 (Atl, E Arc, W Arc); Kenyon and Kenyon 1977 (E Arc); Martineau et al. 1985 (Atl); Wazura et al. 1986 (W Arc)

\section{Pharurus sp.}

Syn.: Pseudostenurus sp. of Smith and Threlfall (1973)

Site: unspecified

Host: Phocoena phocoena

Dist.: Atl

Record: Smith and Threlfall (1973)

Remarks: Anderson (1978) listed

Pseudostenurus Yamaguti, 1951 as a

synonym of Pharurus Leuckart, 1848. In

addition, Arnold and Gaskin (1975)

commented that "the occurrence of the genus

Pseudostenurus in harbor porpoise by Smith and Threlfall (1973) ... needs confirmation.”

Pseudalius inflexus (Rudolphi, 1808) Schneider, 1866

Site: lungs

Host: Phocoena phocoena

Dist.: Atl

Record: Arnold and Gaskin 1975

Stenurus arctomarinus Delyamure and

Kleinenberg, 1958

Site: lungs

Host: Delphinapterus leucas

Dist.: E Arc, W Arc

Record: Arnold and Gaskin 1975 
Stenurus globicephalae Baylis and Daubney, 1925

Sites: trachea, lungs, cranial sinuses

Hosts: Globicephala melaena $(1,2,3)$ Grampus griseus (3)

Dist.: Atl

Records: 1. Cowan 1966; 2. 1967; 3 Arnold and Gaskin 1975

Stenurus minor (Kuhn, 1829) Baylis and Daubney, 1925

Site: lungs

Host: Phocoena phocoena

Dist.: Atl

Record: Arnold and Gaskin 1975

Torynurus convolutus (Kuhn, 1829) Baylis and Daubney, 1925

Sites: respiratory system, esophagus, cranial sinuses

Hosts: Globicephala melaena (1)

Phocoena phocoena $(2,3)$

Dist.: Atl, Pac

Records: 1. Sergeant 1962 (Atl); 2. Arnold and Gaskin 1975 (Atl, Pac); 3. Gibson and Harris 1979 (Atl)

Torynurus dalli (Yamaguti, 1951) Delyamure, 1972

Syn.: Irukanema dalli Yamaguti, 1951 of Smith and Threlfall (1973)

Site: unspecified

Host: Phocoena phocoena

Dist.: Atl

Record: Smith and Threlfall 1973

Remarks: Arnold and Gaskin (1975) suggested that the specimens reported as Irukanema dalli by Smith and Threlfall (1973) may actually be Torynurus convolutus.

\section{UNIDENTIFIED NEMATODA}

Nematoda gen. sp.

Site: unspecified

Host: Erignathus barbatus

Dist.: E Arc

Record: Dunbar 1949

\section{PHYLUM \\ ACANTHOCEPHALA}

\section{CLASS \\ PALAEACANTHOCEPHALA ORDER POLYMORPHIDA \\ FAMILY POLYMORPHIDAE}

Bolbosoma capitatum (von Linstow, 1880) Porta, 1908

Site: intestine

Host: Globicephala melaena

Dist.: Atl

Record: Cowan 1967
Bolbosoma turbinella (Diesing, 1851) Porta, 1908

Site: small intestine

Host: Balaenoptera borealis

Dist.: Pac

Record: Margolis and Pike 1955

Bolbosoma sp.

Site: intestine

Host: Balaenoptera physalus

Dist.: Pac

Record: Previously unpublished

Corynosoma cameroni Van Cleave, 1953

Site: intestine

Host: Delphinapterus leucas

Dist.: Atl

Records: Van Cleave 1953a; 1953b

Corynosoma magdaleni Montreuil, 1958

Site: intestine

Host: Halichoerus grypus

Dist.: Atl

Record: Montreuil 1958

Corynosoma reductum (von Linstow, 1905) Railliet and Henry, 1907

Site: intestine

Host: Phoca hispida

Dist.: E Arc

Record: Van Cleave 1953b

Corynosoma strumosum (Rudolphi, 1802) Lühe, 1904

Syn.: Corynosoma semerme (Forssell, 1904) of Fisher (1952)

Sites: small intestine, stomach

Hosts: Delphinapterus leucas $(1,2)$

Erignathus barbatus (1)

Phoca hispida (1)

Phoca vitulina richardsi $(3,4)$

Dist.: Atl, E Arc, Pac

Records: 1. Lyster 1940 (Atl, E Arc); 2. Vladykov 1944 (Atl); 3. Fisher 1952 (Pac); 4. Margolis 1956 (Pac)

Remarks: Margolis (1956) noted that C. semerme of Fisher (1952) is probably referable to $C$. strumosum.

Corynosoma validum Van Cleave, 1953

Syn.: Corynosoma semerme of Lyster (1940)

Site: small intestine

Host: Erignathus barbatus

Dist.: E Arc

Records: Lyster 1940; Van Cleave 1953b

Remarks: According to Van Cleave (1953b), C. semerme of Lyster (1940) is referable to C validum. 
Corynosoma villosum Van Cleave, 1953

Site: intestine

Host: Eumetopias jubatus

Dist.: Pac

Record: Margolis 1956

Corynosoma wegeneri Heinze, 1934

Syn.: Corynosoma hadweni Van Cleave, 1953

Site: intestine

Host: Phoca hispida

Dist.: E Arc

Record: Van Cleave 1953b

Remarks: Margolis (1955) noted that C. hadweni is a probable synonym of C. wegeneri.

\section{Corynosoma spp.}

Site: intestine

Hosts: Phoca vitulina concolor (1)

Phocoena phocoena (2)

Dist.: Atl, Pac

Records: 1. McClelland 1980c (Atl); 2.

Previously unpublished $(\mathrm{Pac})$

Remarks: A single, immature female specimen found by one of us (L.M.) in Phocoena phocoena from the Pacific coast appears to be referable to $C$. similis Neiland, 1962, but a definite allocation to this species is reserved until further material is obtained.

\section{PHYLUM ARTHROPODA}

CLASS CRUSTACEA SUBCLASS ENTOMOSTRACA

\section{ORDER COPEPODA}

\section{SUBORDER SIPHONOSTOMATOIDA}

\section{FAMILY PENNELLIDAE}

Pennella balaenopterae Koren and Danielssen, 1877

Site: head embedded in blubber, trunk external

Host: Balaenoptera physalus

Dist.: Pac

Records: Cornwall 1927; 1928; 1955

\section{SUBCLASS MALACOSTRACA}

\section{ORDER AMPHIPODA}

\section{FAMILY CYAMIDAE}

Cyamus balaenopterae Barnard, 1932

Site: body surface

Host: Balaenoptera acutorostrata

Dist.: Pac

Record: Margolis 1959

Cyamus boopis Lütken, 1870

Syn.: Paracyamus boopis (Lütken, 1870)
Sars, 1895

Site: body surface

Hosts: Balaenoptera physalus (5)

Megaptera novaeangliae $(1,2,3,4)$

Dist.: Atl, Pac

Records: 1. Cornwall 1928 (Pac); 2. Margolis 1954 (Pac); 3. Leung 1965 (Pac); 4. Brunel 1970 (Atl); 5. Previously unpublished (Atl)

Remarks: The record of $C$. boopis from B. physalus appears to be the first from the fin whale.

Cyamus catodontis Margolis, 1954

Site: body surface

Host: Physeter catodon

Dist.: Pac

Records: Margolis 1954; Leung 1965

Cyamus ceti (Linnaeus, 1758) Lamarck, 1801

Site: not specified

Host: not specified [probably Baelana mysticetus]

Dist.: E Arc

Record: Lincoln and Hurley 1974

Remarks: The locality for this record indicated by Lincoln and Hurley (1974) is Baffin Bay. Although the specific locality could be either in Greenland or in Canada, it is included here. The host was not specified but it was probably $B$. mysticetus, the usual host for this cyamid.

Cyamus erraticus Roussel de Vauzème, 1834

Site: body surface

Host: Balaena glacialis

Dist.: Pac

Record: Margolis 1955

Cyamus mondontis . Lütken, 1870

Site: [body surface]

Host: Monodon monoceros

Dist.: E Arc

Records: Leung 1965; Lincoln and Hurley 1974

Cyamus nodosus Lütken, 1860

Site: [body surface]

Host: unspecified

Dist.: E Arc

Record: Lincoln and Hurley 1974

Remarks: Although Lincoln and Hurley (1974) did not specify the host, the usual host for this cyamid is Monodon monoceros.

Cyamus ovalis Roussel de Vauzeme, 1834

Site: [body surface]

Host: Balaena glacialis

Dist.: Pac (?)

Record: Berzin and Vlasova 1982

Remarks: Berzin and Vlasova (1982) listed C. ovalis from Eubaelena glacialis japonica from Canada in their Table 3. 
Cyamus scammoni Dall, 1872

Site: body surface

Host: Eschrichtius robustus

Dist.: Pac

Records: Margolis 1954; 1955; Cornwall 1955

Cyamus sp.

Site: [base of teeth]

Host: Berardius bairdii

Dist.: Pac

Record: Leung 1965

Remarks: Based on personal observations by one of us (L.M.), this species appears to be distinct from other species of Cyamus, although it is close to $C$. catodontis.

Isocyamus delphini (Guèrin-Méneville, 1836)

Gervais and van Beneden, 1859

Site: body surface

Host: Globicephala melaena

Dist.: Atl

Records: Sergeant 1962; Cowan 1966

Neocyamus physeteris (Pouchet, 1888)

Margolis, 1955

Site: body surface

Host: Physeter catodon

Dist.: Pac

Record: Margolis 1959

Platycyamus sp.

Site: body surface

Host: Berardius bairdii

Dist.: Pac

Record: Leung 1965

\section{CLASS INSECTA SUBCLASS PTERYGOTA \\ ORDER ANOPLURA}

\section{FAMILY ECHINOPHTHIRIIDAE}

Antarctophthirus microchir (Trouessart and

Neumann, 1888) Enderlein, 1906

Site: body surface

Host: Eumetopias jubatus

Dist.: Pac

Records: Margolis 1956; Spencer 1966
Antarctophthirus trichechi (Bohemann, 1865)

Enderlein, 1909

Site: body surface

Host: Odobenus rosmarus

Dist.: E Arc

Record: Spencer 1966

Echinophthirius horridus (Olfers, 1816)

Fahrenholz, 1919

Syn.: Echinophthiriidae gen. sp. of

Fisher (1952)

Site: body surface

Hosts: Phoca groenlandica (4)

Phoca hispida $(2,3)$

Phoca vitulia concolor $(3,5)$

Phoca vitulina richardsi $(1,3)$

Dist.: Atl, E Arc, Pac

Records: 1. Fisher 1952 (Pac); 2. Myers 1959

(E Arc); 3. Spencer 1966 (Atl, E Arc, Pac);

4. Ronald et al. 1970 (Atl); 5. McClelland 1980c (Atl)

\section{CLASS ARACHNOIDEA} ORDER ACARINA

FAMILY HALARACHNIDAE

Halarachne sp.

Site: nasopharynx, nasal cavity

Host: Phoca vitulina richardsi

Dist.: Pac

Records: Fisher 1952; Margolis 1956

Orthohalarachne attenuata (Banks, 1910)

Newell, 1947

Site: nasal sinuses

Host: Callorhinus ursinus

Dist.: Pac

Record: Previously unpublished

Orthohalarachne diminuata (Doetschman, 1944)

Newell, 1947

Sites: lungs, bronchioles

Hosts: Callorhinus ursinus (2)

Eumetopias jubatus (1)

Dist.: Pac

Records: 1. Margolis 1956; 2. Previously unpublished 

HOST-PARASITE LIST 



\section{CLASS MAMMALIA \\ ORDER CETACEA SUBORDER ODONTOCETI}

\section{FAMILY DELPHINIDAE}

Globicephala melaena (Traill, 1809)

- long-finned pilot whale

PROTOZOA (Apicomplexa):

Sarcocystis sp. (Atl)

TREMATODA:

Orthosplanchnus arcticus (Atl)

CESTOIDEA:

Diphyllobothrium sp. (Atl)

Phyllobothrium delphini (Atl)

Phyllobothrium sp. (Atl)

Plicobothrium globicephalae (Atl)

Trigonocotyle lintoni (At)

NEMATODA:

Anisakis simplex (Atl)

Anisakis sp. (Atl)

Stenurus globicephalae (Atl)

Torynurus convolutus (Atl)

ACANTHOCEPHALA:

Bolbosoma capitatum (Atl)

AMPHIPODA:

Isocyamus delphini (Atl)

Grampus griseus (G. Cuvier, 1812)

- Risso's dolphin

NEMATODA:

Stenurus globicephalae (Atl)

Lagenorhynchus albirostris Gray, 1846

- white-beaked dolphin

CESTOIDEA:

Plicobothrium globicephalae (Atl)

NEMATODA:

Anisakis sp. (Atl)

Orcinus orca (Linnaeus, 1758) - killer whale

NEMATODA:

Anisakis simplex $(\mathrm{Pac})$

Pseudorca crassidens (Owen, 1846)

- false killer whale

NEMATODA:

Anisakis sp. (Pac)

\section{FAMILY MONODONTIDAE}

Delphinapterus leucas (Pallas, 1776) - white whale

TREMATODA:

Hadwenius seymouri (W Arc)

Leucasiella arctica (W Arc)

NEMATODA:

Anisakis simplex (Atl, E Arc, W Arc)
Anisakis sp. (E Arc)

Contracaecum sp. (W Arc)

Pharurus pallasii (Atl, E Arc, W Arc)

Pseudoterranova decipiens (Atl)

Stenurus arctomarinus (E Arc, W Arc)

ACANTHOCEPHALA:

Corynosoma cameroni (Atl)

Corynosoma strumosum (Atl)

Monodon monoceros Linnaeus, 1758 - narwhal

NEMATODA:

Halocercus monoceris (E Arc)

Pharurus alatus (E Arc)

AMPHIPODA:

Cyamus monodontis (E Arc)

Cyamus nodosus (?) (E Arc)

\section{FAMILY PHOCOENIDAE}

Phocoena phocoena (Linnaeus, 1758)

- harbor porpoise

TREMATODA:

Campula oblonga (Atl, Pac)

Hadwenius nipponicus (Pac)

NEMATODA:

Anisakis simplex (Pac)

Contracaecum sp. (Atl)

Crassicauda sp. (Pac)

Halocercus invaginatus (Atl, Pac)

Halocercus taurica (Atl, Pac)

Halocercus sp. (Atl)

Pharurus sp. (Atl)

Pseudalius inflexus (Atl)

Pseudoterranova decipiens (Atl)

Stenurus minor (Atl)

Torynurus convolutus (Atl, Pac)

Torynurus dalli (Atl)

ACANTHOCEPHALA:

Corynosoma sp. (?C. similis) (Pac)

Phocoenoides dalli (True, 1885) - Dall's porpoise

TREMATODA:

Campula oblonga $(\mathrm{Pac})$

NEMATODA:

Anisakis simplex $(\mathrm{Pac})$

\section{FAMILY PHYSETERIDAE}

Physeter catodon Linnaeus, 1758 - sperm whale

Syn.: Physeter macrocephalus Linnaeus, 1758

CESTOIDEA:

Phyllobothrium delphini (Pac)

NEMATODA:

Anisakis physeteris (Atl, Pac)

Anisakis simplex (Atl, Pac)

Placentonema gigantissima $(\mathrm{Pac})$ 
AMPHIPODA:

Cyamus catodontis (Pac)

Neocyamus physeteris (Pac)

\section{FAMILY ZIPHIIDAE}

Berardius bairdii Stejneger, 1883

- North Pacific bottle-nosed whale

NEMATODA:

Anisakis simplex $(\mathrm{Pac})$

AMPHIPODA

Cyamus sp. (Pac)

Platycyamus sp. (Pac)

\section{SUBORDER MYSTICETI}

\section{FAMILY BALAENIDAE}

Balaena glacialis Muiller, 1776 - black right whale

Syn.: Eubalena glacialis japonica

(Lacépède, 1818)

AMPHIPODA:

Cyamus erraticus $(\mathrm{Pac})$

Cyamus ovalis $(\mathrm{Pac})$

?Balaena mysticetus Linnaeus, 1758

- bowhead whale

AMPHIPODA:

Cyamus ceti (E Arc)

\section{FAMILY BALAENOPTERIDAE}

Balaenoptera acutorostrata Lacépède, 1804

- minke whale

NEMATODA:

Anisakis simplex (Atl)

AMPHIPODA:

Cyamus balaenopterae (Pac)

Balaenoptera borealis Lesson, 1828 - sei whale

TREMATODA:

Lecithodesmus spinosus ( $\mathrm{Pac})$

Ogmogaster antarcticus $(\mathrm{Pac})$

Ogmogaster plicatus (Pac)

CESTOIDEA:

Cestoidea gen. sp. $(\mathrm{Pac})$

NEMATODA:

Anisakis simplex (Pac)

ACANTHOCEPHALA:

Bolbosoma turbinella $(\mathrm{Pac})$

Balaenoptera physalus (Linnaeus, 1758) - fin whale

Syn.: Balaenoptera velifera Cope, 1869

TREMATODA:

Lecithodesmus goliath $(\mathrm{Pac})$

Ogmogaster plicatus $(\mathrm{Pac})$

CESTOIDEA:

Phyllobothrium delphini (Atl, Pac)
NEMATODA:

Anisakis simplex (Atl)

Anisakis sp. (Pac)

Crassicauda boopis (Pac)

ACANTHOCEPHALA:

Bolbosoma sp. (Pac)

COPEPODA:

Pennella balaenopterae (Pac)

AMPHIPODA:

Cyamus boopis (Atl)

Balaenoptera sp.

TREMATODA:

Ogmogaster plicatus (Pac)

Megaptera novaeangliae (Borowski, 1781)

- humpback whale

Syn.: Megaptera versabilis Cope, 1869

Megaptera nodosa (Bonnaterre, 1789)

CESTOIDEA:

Cestoidea gen. sp. (Pac)

NEMATODA:

Anisakis sp. (Pac)

AMPHIPODA:

Cyamus boopis (Atl, Pac)

\section{FAMILY ESCHRICHTIDAE}

Eschrichtius robustus (Lilljeborg, 1861) - gray whale

Syn.: Rachianectes glaucus Cope, 1868

Eschrichtius glaucus (Cope, 1868)

Eschrichtius gibbosus (Erxleben, 1777)

AMPHIPODA:

Cyamus scammoni $(\mathrm{Pac})$

ORDER CARNIVORA FAMILY ODOBENIDAE

Odobenus rosmarus (Linnaeus, 1758) - walrus

NEMATODA:

Trichinella spiralis (E Arc)

ANOPLURA:

Antarctophthirus trichechi (E Arc)

FAMILY OTARIIDAE

Callorhinus ursinus (Linnaeus, 1758)

- northern fur seal

NEMATODA:

Uncinaria lucasi $(\mathrm{Pac})$

ACARINA:

Orthohalarachne attenuata (Pac)

Orthohalarachne diminuata $(\mathrm{Pac})$

Eumetopias jubatus (Schreber, 1776)

- northern sea lion

CESTOIDEA:

Diphyllobothrium pacificum $(\mathrm{Pac})$

Diplogonoporus tetrapterus (Pac) 


\section{NEMATODA:}

Contracaecum osculatum (Pac)

Parafilaroides sp. (Pac)

Pseudoterranova decipiens (Pac)

ACANTHOCEPHALA:

Corynosoma villosum $(\mathrm{Pac})$

ACARINA:

Orthohalarachne diminuata $(\mathrm{Pac})$

ANOPLURA:

Antarctophthirus microchir (Pac)

\section{FAMILY PHOCIDAE}

Erignathus barbatus (Erxleben, 1777) - bearded seal

Syn.: Phoca barbata Erxleben, 1777

CESTOIDEA:

Cestoidea gen. sp. (E Arc)

Diphyllobothrium cordatum (E Arc, W Arc)

Diphyllobothrium lanceolatum (Atl, E Arc, W Arc)

Diphyllobothrium sp. (E Arc, W Arc)

Diplogonoporus sp. (Atl)

Pyramicocephalus phocarum (E Arc, W Arc)

NEMATODA:

Contracaecum osculatum (E Arc, W Arc)

Nematoda gen. sp. (E Arc)

Pseudoterranova decipiens (E Arc)

Trichinella spiralis (E Arc)

ACANTHOCEPHALA:

Corynosoma strumosum (E Arc)

Corynosoma validum (E Arc)

Halichoerus grypus (Fabricius, 1791) - gray seal

NEMATODA:

Anisakinae gen. sp. (Atl)

Anisakis sp. (Atl)

Contracaecum osculatum (Atl)

Contracaecum sp. (Atl)

Pseudoterranova decipiens (Atl)

ACANTHOCEPHALA:

Corynosoma magdaleni (Atl)

Phoca groenlandica Erxleben, 1777 - harp seal

Syn.: Pagophilus groenlandicus

(Erxleben, 1777)

CESTOIDEA:

Anophryocephalus anophrys (Atl)

Diphyllobothrium lanceolatum (Atl, E Arc)

Diphyllobothrium sp. (E Arc)

Diplogonoporus sp. (Atl)

NEMATODA:

Anisakinae gen. sp. (Atl)

Anisakis sp. (Atl)

Contracaecum osculatum (Atl, E Arc)

Contracaecum sp. (Atl)

Pseudoterranova decipiens (Atl, E Arc)

ANOPLURA:

Echinophthirius horridus (Atl)
Phoca hispida Schreber, 1775 - ringed seal

Syn.: Pusa hispida (Schreber, 1775)

TREMATODA:

Orthosplanchnus arcticus (W Arc)

NEMATODA:

Contracaecum osculatum (E Arc, W Arc)

Contracaecum sp. (E Arc)

Filaroides (Parafilaroides) hispidus (W Arc)

Phocascaris netsiki (E Arc)

Pseudoterranova decipiens (E Arc)

ACANTHOCEPHALA:

Corynosoma reductum (E Arc)

Corynosoma strumosum (E Arc)

Corynosoma wegeneri (E Arc)

ANOPLURA:

Echinophthirius horridus (E Arc)

Phoca vitulina concolor De Kay, 1842 - harbor seal

PROTOZOA (Apicomplexa):

Eimeria phocae (Atl)

CESTOIDEA:

Anophryocephalus sp. (Atl)

NEMATODA:

Anisakinae gen. sp. (Atl)

Anisakis sp. (Atl)

Contracaecum osculatum (Atl, E Arc)

Contracaecum sp. (Atl)

Dipetalonema spirocauda (Atl)

Phocascaris netsiki (E Arc)

Pseudoterranova decipiens (Atl, E Arc)

ACANTHOCEPHALA:

Corynosoma sp. (Atl)

ANOPLURA:

Echinophthirius horridus (Atl)

Phoca vitulina richardsi (Gray, 1864) - harbor seal

NEMATODA:

Contracaecum osculatum (Pac)

Pseudoterranova decipiens (Pac)

ACANTHOCEPHALA:

Corynosoma strumosum (Pac)

ANOPLURA:

Echinophthirius horridus (Pac)

ACARINA:

Halarachne sp. (Pac)

Records for pinnipeds of undetermined species

"seal"

NEMATODA:

Phocascaris netsiki (E Arc)

"seals"

NEMATODA:

Pseudoterranova decipiens (Atl, E Arc) 
AMIN, O. M. 1985. Classification, p. 27-72. In D. W. T. Crompton and B. B. Nickol [ed.] Biology of the Acanthocephala. Cambridge University Press, London.

ANDERSON, R. C. 1978. Keys to genera of the superfamily Metastrongyloidea. In R. C. Anderson, A. G. Chabaud, and S. Willmott [ed.] CIH Keys to the nematode parasites of vertebrates, No. 5, 40 p. Commonwealth Agricultural Bureaux, Farnham Royal, Bucks, England.

ANDERSON, R. C., A. G. CHABAUD, and S. WILMOTT [ed.]. 1974-1983. CIH Keys to the nematode parasites of vertebrates, No. 1-10. Commonwealth Agricultural Bureaux, Farnham Royal, Bucks, England.

ARNOLD, P. W., and D. E. GASKIN. 1975. Lungworms (Metastrongyloidea: Pseudaliidae) of harbor porpoise Phocoena phocoena (L. 1758). Canadian Journal of Zoology 53: 713-735.

BAER, J. G. 1954. Revision taxinomique et étude biologique des cestodes de la famille des Tetrabothriidae parasites d'oiseaux de haute mer et de mammifères marins. Mémoire de l'Université de Neuchatel, Série in-quarto, No. 1: $121 \mathrm{p}$.

BAIRD, W. 1853. Catalogue of the species of Entozoa or intestinal worms contained in the collection of the British Museum, London. Woodfall and Kinder, London. 132 p.

BANKS, R. C., R. W. McDIARMID, and A. L. GARDNER. 1987. Checklist of vertebrates of the United States, the U.S. Territories, and Canada. United States Fish and Wildlife Service, Resource Publication 166: 79 p.

BERZIN, A. A., and L. P. VLASOVA. 1982. Fauna of the Cetacea Cyamidae (Amphipoda) of the world ocean, p. 149-164. In G. Pilleri [ed.] Investigations on Cetacea, Vol. 13. Berne, Switzerland.

BIGG, M. A., and E. T. LYONS. 1981. Clinical observations on three northern fur seal pups treated with dichlorvos. Journal of the American Veterinary Association 179: 1284-1286.

BRODIE, P. F. 1971. A reconsideration of aspects of growth, reproduction, and behaviour of the white whale (Delphinapterus leucas), with reference to the Cumberland Sound, Baffin Island, population. Journal of the Fisheries Research Board of Canada 28: 1309-1318.
BROOKS, D. R., R. T. O'GRADY, and D. R. GLEN. 1985. Phylogenetic analysis of the Digenea (Platyhelminthes: Cercomeria) with comments on their adaptive radiation. Canadian Journal of Zoology 63: 411-443.

BRUNEL, P. 1970. Catalogue dinvertębrés benthiques du golfe Saint-Laurent recueillis de 1951 à 1966 par la Station de Biologie marine de Grand-Rivière. Travaux sur les Pêcheries du Québec. No. 32, 55 p.

COOPER, A. R. 1921. Trematodes and cestodes of the Canadian Arctic Expedition. Report of the Canadian Arctic Expedition, 1913-18, No. 9, Parts G-H: 1-27.

CORNWALL, I. E. 1927. Some North Pacific whale barnacles. Contributions to Canadian Biology and Fisheries, New Series 3: 501-517.

1928. Collecting at Cachalot Whaling Station. Canadian Field-Naturalist 42: 9-12.

1955. The barnacles of British Columbia. British Columbia Provincial Museum. Department of Education. Handbook No. 7: 69 p.

COWAN, D. F. 1966. Pathology of the pilot whale Globicephala melaena. A comparative survey. Archives of Pathology 82: 178-189.

1967. Helminth parasites of the pilot whale Globicephala melaena (Traill, 1809). Journal of Parasitology 53: 166-167.

DAILEY, M., and R. STROUD. 1978. Parasites and associated pathology observed in cetaceans stranded along the Oregon coast. Journal of Wildlife Diseases 14: 503-511.

DAVEY, J. T. 1971. A revision of the genus Anisakis Dujardin, 1845 (Nematoda: Ascaridata). Journal of Helminthology 45: 51-72.

DOAN, K. H., and C. W. DOUGLAS. 1953. Beluga of the Churchill region of Hudson Bay. Bulletin of the Fisheries Research Board of Canada 98: 27 p.

DUNBAR, M. J. 1949. The Pinnipedia of the Arctic and Subarctic. Bulletin of the Fisheries Research Board of Canada 85: 22 p.

FISHER, H. D. 1952. The status of the harbour seal in British Columbia, with particular reference to the Skeena River. Bulletin of the Fisheries Research Board of Canada 93: 58 p. 
GIBSON, D.I. 1983. The systematics of ascaridoid nematodes .. a current assessment, p. 321-338. In A.R. Stone, H.M. Platt, and L.F. Khalil [ed.] Concepts in nematode systematics. Systematics Association Special Volume No. 22.

GIBSON, D.I. 1987. Questions in digenean systematics and evolution. Parasitology 95: 429-460.

GIBSON, D.I., and J.A. COLIN. 1982. The Terranova enigma. Parasitology 85 : xxxvi-xxxvii.

GIBSON, D.I., and E.A. HARRIS. 1979. The helminth-parasites of cetaceans in the collection of the British Museum (Natural History), p. 309-324. In G. Pilleri [ed.] Investigations on Cetacea, Vol. 10. Berne, Switzerland.

GUIART, J. 1935. Cestodes parasites provenant des campagnes scientifiques de S.A.S. le Prince Albert Ier de Monaco (1866-1913). Résultats des Campagnes Scientifiques Accomplies sur son Yacht par Albert Ier Prince Souverain de Monaco, Fascicule 91: 115 p. +5 plates.

KENNEDY, M.J. 1986. Filaroides (Parafilaroides) hispidus n.sp. (Nematoda: Metastrongyloidea) from the lungs of the ringed seal, Phoca hispida (Phocidae), from the Beaufort Sea, Canada. Canadian Journal of Zoology 64: 1864-1868.

KENYON, A.J., and B.J. KENYON. 1977. Prevalence of Pharurus pallasii in the beluga whale (Delphinapterus leucas) of Churchill River basin, Manitoba. Journal of Wildlife Diseases 13: 338-340.

KUITUNEN-EKBAUM, E. 1954. Walrus meat as a source of trichinosis in Eskimos. Canadian Journal of Public Health 45: 30.

LAMBERTSEN, R.H. 1985. Taxonomy and distribution of a Crassicauda species (Nematoda: Spirurida) infecting the kidney of the common fin whale (Balaenoptera physalus Linné, 1758). Journal of Parasitology 71: 485-488.

LEUNG, Y.M. 1965. A collection of whale-lice (Cyamidae: Amphipoda). Bulletin of the Southern California Academy of Sciences 64: 132-143.

LEVINE, N.D., J.O. CORLISS, F E.G. COX, G. DEROUX, J. GRAIN, B.M. HONIGBERG, G.F. LEEDALE, A.R. LOEBLICH, III, J. LOM, D. LYNN, E.G. MERINFELD, F.C. PAGE, G. POLJANSKY, MERINFELD, F.C. PAGE, G. POLJANSKY, V. SPRAGUE, J. VAVRA, and F.G. WALLACE. 1980. A newly revised classification of the Protozoa. Journal of Protozoology 27: 37-58.
LINCOLN, R.J., and D.E. HURLEY. 1974.

Catalogue of the whale-lice (Crustacea: Catalogue of the whale-lice (Crustacea: Amphipoda: Cyamidae) in the collection of the British Museum (Natural History). Bulletin of the British Museum (Natural History) 27: 65-72.

LYONS, E. T., and M. A. BIGG. 1983. On the longevity of larvae of the hookworm Uncinaria lucasi in tissues of northern fur seals (Callorhinus ursinus). Journal of Parasitology 69: 442-443.

LYSTER, L.L. 1940. Parasites of some Canadian sea mammals. Canadian Journal of Research 18D: $395-409$.

MACNEIL, A.C., J.L. NEUFELD, and W.A. WEBSTER. 1975. Pulmonary nematodiasis in a narwhal. Canadian Veterinary Journal 16: 53-55.

MANSFIELD, A.W. 1963. Seals of Arctic and eastern Canada. Bulletin of the Fisheries Research Board of Canada 137: $30 \mathrm{p}$.

MANSFIELD, A.W., and B. BECK. 1977. The grey seal in eastern Canada. Environment Canada, Fisheries and Marine Service Technical Report 704: 81 p.

MARGOLIS, L. 1954. Three kinds of whale-lice (Cyamidae: Amphipoda) from the Pacific coast of Canada, including a new species. Journal of the Fisheries Research Board of Canada 11: 319-325.

1955. Notes on the morphology, taxonomy and synonymy of several species of whale-lice (Cyamidae: Amphipoda). Journal of the Fisheries Research Board of Canada 12: 121-133.

1956. Parasitic helminths and arthropods from Pinnipedia of the Canadian Pacific coast. Journal of the Fisheries Research Board of Canada 13: 489-505.

1959. Records of Cyamus balaenopterae Barnard and Neocyamus physeteris (Pouchet), two species of whale-lice (Amphipoda), from the northeast Pacific. Canadian Journal of Zoology 37: 895-897.

MARGOLIS, L., and J.R. ARTHUR. 1979. Synopsis of the parasites of fishes of Canada. Bulletin of the Fisheries Research Board of Canada 199: 269 p. 
MARGOLIS, L., and M.D. DAILEY. 1972.

Revised annotated list of parasites from sea mammals caught off the west coast of North America. NOAA Technical Report NMFS SSRF-647. U.S. Department of Commerce, Seattle, Washington. $23 \mathrm{p}$.

MARGOLIS, L., and G.C. PIKE. 1955. Some helminth parasites of Canadian Pacific whales. Journal of the Fisheries Research Board of Canada 12: 97-120.

MARKOWSKI, S. 1952. The cestodes of pinnipeds in the Arctic and other regions. Journal of Helminthology 26: 171-214.

MARTINEAU, D., A. LAGACÉ, R. MASSÉ, M. MORIN, and P. BÉLAND. 1985.

Transitional cell carcinoma of the urinary bladder in a beluga whale (Delphinapterus leucas). Canadian Veterinary Journal 26: 297-302.

McCLELLAND, G. 1976. Terranova decipiens (Nematoda: Anisakinae): course of infection and pathology in seal hosts. Transactions of the American Microscopical Society 95: 265.

1980a. Phocanema decipiens: molting in seals. Experimental Parasitology 49: 128-136.

1980b. Phocanema decipiens: growth, reproduction and survival in seals. Experimental Parasitology 49: 175-187.

1980c. Phocanema decipiens: pathology in seals. Experimental Parasitology 49: 405-419.

1982. Phocanema decipiens (Nematoda: Anisakinae): experimental infections in marine copepods. Canadian Journal of Zoology 60: 502-509.

McCLELLAND, G., R.K. MISRA, and D.J. MARTELL. 1987. Temporal and geographical variations in abundance of larval sealworm, Pseudoterranova (Phocanema) decipiens, in the fillets of American plaice (Hippoglossoides platessoides) in eastern Canada: 1985-86 surveys. Canadian Technical Report of Fisheries and Aquatic Sciences 1513: 15 p.

McCLELLAND, G., and K. RONALD. 1970. The in vitro growth and development of the early larval stages of the codworm, Terranova decipiens. Canadian Journal of Zoology 48 : 198-199.
McCLELLAND, G., and K. RONALD. 1974. In vitro development of Terranova decipiens (Nematoda) (Krabbe, 1878). Canadian Journal of Zoology 52: 471-479.

MONTREUIL, P.L. 1958. Corynosoma magdaleni sp. nov. (Acanthocephala), a parasite of the gray seal in eastern Canada. Canadian Journal of Zoology 36: 205-215.

MONTREUIL, P.L., and K. RONALD. 1957. A preliminary note on the nematode parasites of seals in the Gulf of the St. Lawrence. Canadian Journal of Zoology 35:495.

MUELLER, J.F. 1927a. The excretory system of Anisakis simplex. Zeitschrift für Wissenschaftliche Biologie, Abt. B. Zeitschrift für Zellforschung and mikroskopische Anatomie 5: 495-504.

1927b. The excretory system of Anisakis simplex. Journal of Parasitology 13: 222.

MYERS, B.J. 1957a. Nematode parasites of seals in the eastern Canadian Arctic. Canadian Journal of Zoology 35: 291.

1957b. Ascaroid parasites of harp seals (Phoca gröenlandica Erxleben) from the Magdalen Islands, Quebec. Canadian Journal of Zoology 35: 291-292.

1959. Lice on Phoca hispida Schreber. Canadian Journal of Zoology 37: 1123.

1960. On the morphology and life history of Phocanema decipiens (Krabbe, 1878) Myers, 1959 (Nematoda: Anisakidae). Canadian Journal of Zoology 38: 331-344.

NEWMAN, M.A., and P.L. McGEER. 1966. The capture and care of a killer whale, Orcinus orca, in British Columbia. Zoologica, New York 51: 59-70.

RAUSCH, R.L., and F.H. FAY. 1966. Studies on the helminth fauna of Alaska. XLIV. Revision of Ogmogaster Jägerskiöld, 1891, with a description of $O$. pentalineatus sp. $\mathrm{n}$. (Trematoda: Notocotylidae). Journal of Parasitology 52: 26-38.

RAUSCH, R.L., and L. MARGOLIS. 1969. Plicobothrium globicephalae gen. et sp. nov. (Cestoda: Diphyllobothriidae) from the pilot whale, Globicephala melaena Traill, in Newfoundland waters. Canadian Journal of Zoology 47: 745-750. 
RONALD, K., E. JOHNSON, M. FOSTER, and D. VANDER POL. 1970. The harp seal, Pagophilus groenlandicus (Erxleben, 1777). I. Methods of handling, molt, and diseases in captivity. Canadian Journal of Zoology 48: 1035-1040.

SCHMIDT, G.D. 1986. Handbook of tapeworm identification. CRC Press, Boca Raton, Florida. 675 p.

SCOTT, D.M. 1950. A preliminary report on the cod-worm investigation. Fisheries Research Board of Canada Atlantic Progress Report No. 48: $10-12$.

1953. Experiments with the harbor seal, Phoca vitulina, a definitive host of a marine nematode, Porrocaecum decipiens. Journal of the Fisheries Research Board of Canada 10: 539-547.

1955. On the early development of Porrocaecum decipiens. Journal of Parasitology 41: 321-322.

SCOTT, D.M., and W.F. BLACK. 1960. Studies on the life-history of the ascarid Porrocaecum decipiens in the Bras d'or lakes, Nova Scotia, Canada. Journal of the Fisheries Research Board of Canada 17: 763-774.

SCOTT, D.M., and H.D. FISHER. 1958a. Incidence of a parasitic ascarid, Porrocaecum decipiens, in the common porpoise, Phocoena phocoena, from the lower Bay of Fundy. Journal of the Fisheries Research Board of Canada 15: 1-4.

1958b. Incidence of the ascarid Porrocaecum decipiens in the stomachs of three species of seals along the southern Canadian Atlantic mainland. Journal of the Fisheries Research Board of Canada 15: 495-516.

SERGEANT, D.E. 1962. The biology of the pilot or pothead whale Globicephala melaena (Traill) in Newfoundland waters. Bulletin of the Fisheries Research Board of Canada 132: 84 p.

SERGEANT, D.E., and H.D. FISHER. 1957. The smaller Cetacea of eastern Canadian waters. Journal of the Fisheries Research Board of Canada 14: 83-115.

SHAUGHNESSY, P.D., and F.H. FAY. 1977. A review of the taxonomy and nomenclature of the North Pacific harbour seals. Journal of Zoology, London 182: 385-419.
SMITH, F.R., and W. THRELFALL. 1973.

Helminths of some mammals from

Newfoundland. American Midland Naturalist 90: 215-218.

SOLEIM, O. 1984. A synopsis of the genera Thynnascaris and Contracaecum (Nematoda, Ascaridoidea) with an emendation of the generic definitions. Acta Parasitologica Polonica 29: 85-96.

SPENCER, G.J. 1966. Anoplura from British Columbia and some adjacent areas. Journal of the Entomological Society of British Columbia 63: 23-30.

STUNKARD, H.W. 1948. Pseudophyllidean cestodes from Alaskan pinnipeds. Journal of Parasitology 34: 211-228.

VAN CLEAVE, H.J. 1953a. A preliminary analysis of the acanthocephalan genus Corynosoma in mammals of North America. Journal of Parasitology 39: 1-13.

1953b. Acanthocephala of North American mammals. Illinois Biological Monographs 23: $179 \mathrm{p}$.

VLADYKOV, V.D. 1944. Etudes sur les mammifères aquatiques. III. - Chasse, biologie et valeur économique du Marsouin Blanc ou Béluga (Delphinapterus leucas) du fleuve et du golfe Saint-Laurent. Département des Pêcheries, Québec. Contribution No. 14: 194 p.

WAZURA, K.W., J.T. STRONG, C.L. GLENN, and A.O. BUSH. 1986. Helminths of the beluga whale (Delphinapterus leucas) from the Mackenzie River delta, Northwest Territories. Journal of Wildlife Diseases 22: 440-442.

WARDLE, R.A., J.A. McLEOD, and I.E. STEWART. 1947. Lühe's "Diphyllobothrium" (Cestoda). Journal of Parasitology 33: 319-330.

WEBSTER, W.A., J.L. NEUFELD, and A.C. MacNEILL. 1973. Halocercus monoceris sp. n. (Nematoda: Metastrongyloidea) from the narwhal, Monodon monoceros. Proceedings of the Helminthological Society of Washington 40: $255-258$.

WILSON, T.M. and P.H. STOCKDALE. 1970. The harp seal, Pagophilus groenlandicus (Erxleben, 1777). XI. Contracaecum sp. infestation in a harp seal. Journal of Wildlife Diseases 6: 152-154. 


\section{Parasites}

Acanthocephala

Acarina

Adenophorea

Amphipoda

Ancylostomatidae

Ancylostomatoidea

Anisakidae

Anisakinae gen. sp.

Anisakis physeteris

Anisakis simplex

Anisakis sp.

Anophryocephala sp.

see Anophryocephalus sp.

Anophryocephalus anophrys

Anophryocephalus sp.

Anoplura

Antarctophthirus microchir

Antarctophthirus trichechi

Apicomplexa

Arachnoidea

Arthropoda

Ascaridida

Ascaridoidea

Ascaris osculata

see Contracaecum osculatum

Bolbosoma capitatum

Bolbosoma turbinella

Bolbosoma sp.

Bothriocephalus anthocephalus see Pyramicocephalus phocarum

Campula oblonga

Campulidae

Cestoidea

Cestoidea gen. sp.

Coccidia

Contracaecum osculatum

Contracaecum spp.

Copepoda

Cordicephalus phocarus

see Diphyllobothrium lanceolatum and Diplogonoporus sp.

Corynosoma cameroni

Corynosoma hadweni see Corynosoma wegeneri

Corynosoma magdaleni

Corynosoma reductum

Corynosoma semerme

see Corynosoma strumosum and

Corynosoma validum

Corynosoma (?) similis

Corynosoma strumosum
Page

Page

11

Corynosoma validum

Corynosoma villosum

Corynosoma wegeneri

Corynosoma spp.

Crassicauda boopis

Crassicauda pacifica see Crassicauda boopis

Crassicauda sp. see also Pharurus pallasii

Crustacea

Cyamidae

Cyamus balaenopterae

Cyamus boopis

Cyamus catodontis

Cyamus ceti

Cyamus erraticus

Cyamus monodontis

Cyamus nodosus

Cyamus ovalis

Cyamus scammoni

Cyamus sp.

Cyclophyllidea

Digenea

Dipetalonema spirocauda

Diphyllobothriidae

Diphyllobothrium cordatum

Diphyllobothrium lanceolatum

Diphyllobothrium pacificum

Diphyllobothrium spp.

Diplogonoporus tetrapterus

Diplogonoporus sp.

Echinophthiriidae

Echinophthiriidae gen. sp. see Echinophthirius horridus

Echinophthirius horridus

Echinostomatiformes

Eimeria phocae

Eimeriidae

Eimeriina

Enoplida

Entomostraca

Eucoccidiida

Eucestoda

Fascioloidea

Filarioidea

Filaroididae

Filaroides (Parafilaroides) hispidus

Filaroides (Parafilaroides) sp.

Habronematoidea

Hadwenius nipponicus 
Hadwenius seymouri 5

Halarachne sp. $\quad 13$

Halarachnidae $\quad 13$

Halocercus inflexicaudatus see Halocercus invaginatus

Halocercus invaginatus $\quad 10$

Halocercus monoceris $\quad 10$

Halocercus taurica $\quad 10$

Halocercus sp. $\quad 10$

Insecta

Irukanema dalli see Torynurus dalli

Isocyamus delphini

Lecithodesmus goliath

Lecithodesmus spinosus

Leucasiella arctica

Malacostraca

Metastrongyloidea

Nemathelminthes 7

Nematoda $\quad 7$

Nematoda gen. sp.

Neocyamus physeteris

Notocotylidae

Notocotyloidea

Ogmogaster antarcticus

Ogmogaster plicatus

Onchocercidae

Orthohalarachne attenuata

Orthohalarachne diminuata

Orthosplanchnus arcticus

Palaeacanthocephala

Paracyamus boopis see Cyamus boopis

Parafilaroides sp. see Filaroides (Parafilaroides) sp.

Paramphistomiformes

Pennella balaenopterae

Pennellidae

Pharurus alatus

Pharurus pallasii

Pharurus sp.

Phocanema decipiens see Pseudoterranova decipiens

Phocascaris netsiki
Phyllobothriidae 6

Phyllobothrium delphini 6

Phyllobothrium sp. 7

Placentonema gigantissima 9

Platycyamus sp. $\quad 13$

Platyhelminthes 5

Plicobothrium globicephalae 6

Polymorphidae 11

Polymorphida 11

Porrocaecum decipiens see Pseudoterranova decipiens

Protozoa 5

Pseudaliidae 10

Pseudalius inflexus $\quad 10$

Pseudophyllidea $\quad 6$

Pseudostenurus sp. see Pharurus sp.

Pseudoterranova decipiens 9

Pterygota $\quad 13$

Pyramicocephalus phocarum 6

Sarcocystidae 5

Sarcocystis sp. 5

Secernentea 7

Siphonostomatoida $\quad 12$

Spirurida 9

Sporozoea 5

Stenurus arcticus

see Pharurus pallasii

Stenurus arctomarinus $\quad 10$

Stenurus globicephalae $\quad 11$

Stenurus minor $\quad 11$

Strongylida 9

Terranova decipiens see Pseudoterranova decipiens

Tetrabothriidae 7

Tetrameridae 9

Tetraphyllidea 6

Torynurus convolutus $\quad 11$

Torynurus dalli 11

Trematoda 5

Trichinella spiralis $\quad 7$

Trichinellidae $\quad 7$

Trichinelloidea 7

Trigonocotyle lintoni $\quad 7$

Uncinaria lucasi $\quad 10$

Phocascaris sp. see Contracaecum spp. 
Hosts

Page

Page

Balaena glacialis

18

?Balaena mysticetus

Megaptera novaeangliae

Balaenidae

18

Balaenoptera acutorostrata

18

18

Balaenoptera borealis

Balaenoptera physalus

Balaenoptera velifera see Balaenoptera physalus

Balaenoptera sp.

Balaenopteridae

Berardius bairdii

Callorhinus ursinus

Carnivora

Cetacea

Delphinapterus leucas

Delphinidae

Erignathus barbatus

Eschrichtidae

Eschrichtius gibbosus see Eschrichtius robustus

Eschrichtius glaucus see Eschrichtius robustus

Eschrichtius robustus

Eubalaena glacialis japonica see Balaena glacialis

Eumetopias jubatus

Globicephala melaena

Halichoerus grypus

Lagenorhynchus albirostris

Megaptera nodosa see Megaptera novaeangliae

Megaptera versabilis see Megaptera novaeangliae

Monodon monoceros

$\begin{array}{ll}\text { Monodontidae } & 17\end{array}$

Mysticeti 18

Odobenidae $\quad 18$

Odobenus rosmarus $\quad 18$

Odontoceti 17

Orcinus orca $\quad 17$

$\begin{array}{ll}\text { Otariidae } & 18\end{array}$

Pagophilus groenlandicus see Phoca groenlandica

Phoca barbata see Erignathus barbatus

$\begin{array}{ll}\text { Phoca groenlandica } & 19\end{array}$

Phoca hispida 19

Phoca vitulina concolor $\quad 19$

Phoca vitulina richardsi 19

$\begin{array}{ll}\text { Phocidae } & 19\end{array}$

Phocoena phocoena 17

$\begin{array}{ll}\text { Phocoenidae } & 17\end{array}$

Phocoenoides dalli $\quad 17$

$\begin{array}{ll}\text { Physeter catodon } & 17\end{array}$

Physeter macrocephalus see Physeter catodon

$\begin{array}{ll}\text { Physeteridae } & 17\end{array}$

Pseudorca crassidens $\quad 17$

Pusa hispida see Phoca hispida

Rachianectes glaucus see Eschrichtius robustus

Unidentified seals

Ziphiidae 





